\title{
Beyond History: A New Historical Reading of Ashour's Al Tantoureya and Morrison's Beloved
}

Fatma Khalil Aldiwani

Lecturer of English language and literature Misr university of science and technology 
The true homeland is not that which is known or proved. The land which emerges as if from a chemical equation or an institute of theory is not a homeland. Your insistent need to demonstrate the history of stones and your ability to invent proofs does not give you prior membership over him who knows the time of the rain from the smell of the stone. The stone for you is an intellectual effort. For its owner it is a roof and walls (Darwish, 64).

The definition of home greatly depends upon the theory of power and discourse. The concept of home both reflects and shapes the representation of history. History and culture are always dominated and controlled by power which leads to the fact that "the culture that is dominated by another is often lost to history because it is the powerful who has the resources to record that history" (Cawn, 47). This study adopts a new-historical reading of Toni Morrison's Beloved (1987) and Radwa Ashour's Al-Tantoureya (2010) with special concern with the power of discourse in reshaping historical truths. The authors of these two novels attempt to recreate and represent the forged history of two cultures that have long been misrepresented and abused: the African American and the Palestinian cultures.

Tackling history has changed throughout time; previously, history was mainly engaged in proving truths conveyed by "recognized authorities"; however, modern historians - or New Historicists - have gained more awareness "of their own use of language and the language of their sources" in the sense that the sources from which we gain our information regarding the past are like "opaque windows of frosted glass...that both reveal and conceal what is on the other side" ( Rigney, 122). That is, the already existing texts are both possible reflections of past eras and experiences, and are in 
themselves object to investigation and reconsideration. New-historians argue that "the truth of a foreign or past culture can never be known as established and unchangeable", in the sense that believing and interpreting this truth differs from one party to another (Cawn, 47). That is, history is a subject that is not unchangeable; not a static truth that must be passed blindly from one generation to another. On the contrary, history is frequently subject to change and reinterpretation due to the "disparity between the relevance of topics and the availability of evidence with which to treat them" (Regney, 2). Historical texts recording the past are no more than documentations of events that took place in times prior our own. These documentations were written with an aim - most probably political - on behalf of the stronger and powerful authoritative voices. Still, generally, whenever we read historical texts, we honor and accept them for the value of the eras they represent, with "the ethics of objectivity, neutrality and truth-seeking" (Jenkins, 9). However, this past is subjective and relies on individual interpretations and beliefs. This subjective nature of history gives it credit and helps in rendering it a continuous subject of research and investigation; a company for " anybody without a trace of jealousy or a hint of permanent fidelity to any particular caller" ( Jenkins, $10)$.

Hence, the main difference between historicism and new-historicism lies in the fact that historicists are interested in tracing the resemblance of the literary text to history, whereas new-historicists tend to unveil the hidden historical dimensions created through discourse imposed by power and " [ to recover] lost histories and [ explore] mechanisms of repression and subjugation" (Felluga, 1). One of the most influential critics whose theories on the implication of power on the formation of history have long sustained newhistorical studies is Michel Foucault. Foucault is one of the most prominent 
and influential historian-philosophers who argues that "history is the complex interrelationship of a variety of discourses" ( Bressler, 220). His argument is based on the power of discourse on the formation of culture, as well as the effect of the dominant power on this discourse. Foucault has always been fascinated by history, but the history he is concerned with is 'critical' history; one which is there "to prove that there is no intellectually respectable continuity between past concerns and their modern transformations" (Hamilton, 116). History for him is changeable; and any attempt to study it as continuous is "comprised by the subject unified across time which it serves" ( Hamilton, 116). He argues further that this control of the dominant must be counterattacked by the voice of the suppressed and dominated. That is, as history is constructed through the discourse of the dominant power, why can't it be reconstructed by that of the dominated one? This brings us to the newhistorical approach that assumes the impossibility of the resemblance of the culture and history presented in a literary text to its counterpart real one. That is, since history is "knowledge based on the mediation of publicly available sources", then these sources must be reexamined and restudied to understand the underlying forces that shaped this long-believed-in history (Rigney, 121).

If we come to apply Foucault's concept of the power/discourse relationship, we will find that the historical truths of both African Americans and Palestinians have been tarnished through time and replaced by fake historical presentations created and propagated by the colonizing power; either the American or the Jewish one. Toni Morrison, in one of her interviews, claims this power of discourse in reviewing history and established facts saying:

When verbal communication is suppressed or when the language and ways of communication used by the majority do not fit the needs of 
the minority, minority people subvert communication to fit their own needs" ("Scars and Self-definition in Beloved", 1)

This takes us to Foucault's principle of the Gaze. The Gaze is defined as "the ideological mechanism which from the perspective of dominant groups constructs, perpetuates, and determines the identity of the subaltern. It is not only a mechanism but also a controlling force... [ through which] one's identity is constructed" ( Ruman, 1). The concept of gaze "is concerned with the relations of power... [and] carries the sense of being objectified, subordinated, or threatened by the 'look' of another" ( Ruman, 1). As far as this study is concerned, the gaze stands for the White Americans' and Jews' standards of beauty and ugliness, of justice and injustice, and of acceptable and unacceptable. The effect of this view as well as the discourse of the dominant power leads to the loss of identity and freedom on the part of the dominated victims. However, this view cannot be applied equally to both novels due to the various differences - despite the similar essence - among both experiences. In Beloved the Whites' ideologies form the mechanism that constructs, governs and controls the blacks' behavior and identity. Whereas in the case of Al-Tantoureya, the power of the Jewish discourse does not affect the Palestinians' view of themselves or their identities; it has rather shaped the world's view of this nation as one that fights for no rightful cause and that lacks any chance of pursuing a normal life on a usurped homeland.

Therefore, both novels are attempts to uncover the buried truths whose revealance has the power to change the world's views concerning two of the most influential experiences in the history of humanity. This is done through retelling the history of two private family stories as related by their female protagonists. That is, each novel serves as a personal saga reflecting a general social and political history. They give voice to two marginalized 
peoples who have long been deprived of speaking out for themselves, and who have suffered in the course of history from what is known as Diaspora. Either the enslaved African Americans or the Palestinians have been plunked off their natural homelands and families and thrown into the unknown. The term 'Diaspora' was originally coined to "reflect the scattered colonies of exiled Jews outside of Palestine; it has come to mean the forced migration of other groups as well" ( Awilentz, 385). That is, whenever peoples who share common cultural and ethnic identities are "dispersed into hostile environments, there emerges simultaneously a culture which retains many of the residual traditions while attempting to cope with the alien - and most often - dominant society around them"( Awilentz, 385). Thus, both African Americans and Palestinians can be described as diasporized peoples who have been forced- for different causes- out of their original lands and placed in societies in which they have to live and adapt. The two novels under study are the stories of two female victims who experience diasporic lives. That is, not only do the protagonists of these novels stand for these landmark experiences; they also highlight the role of females - especially mothers - in making and preserving history. Both authors use memory as the storehouse of the forgotten truth of these two races; a technique that requires the use of specific parallel narrative elements that suit this unique human power known as memory. Therefore, this research does not move chronologically with the events of the stories; on the contrary, like memory, it jumps from one point to another in an attempt to understand as well as convey the authors' messages.

The new-historical approach in tackling the African- American issue is described by Morrison herself saying

Our silence has been long and deep. In canonical literature, we've always been spoken for. Or we have been spoken to. Or we have 
appeared as jokes or as flat figures suggesting sensuality. Today we are taking back the narrative, telling our own story (in Gates, 89)

That is why Morrison chooses in Beloved to reflect the real, mutated story which has long been told by white narrators. Beloved, as other slave narratives or contemporary novels of slavery, tends to present an authentic "moral" history based on "memory, knowledge, and identity" (Rody, 85). The novel does not deny the history known to people; but it gives the opposite face of the coin to render a full picture for the reader to decide and judge. Sethe, the protagonist, is an African American slave who - like other slaves works on a plantation and suffers all sorts of cruelty and humiliation adopted by slaveholders. Sethe is drawn after Margaret Garner, a real slave who killed her children to protect them from this destructive institution. The novel is set in the period following the end of the Civil War, during the era of Reconstruction, when a great deal of random violence was let loose upon Blacks - either the slaves freed by the Emancipation or those who bought their freedom earlier. During the time period known as the Middle Passage, Sethe the protagonist of the novel under study - attempts to escape slavery. Nevertheless, she is followed by her former master, the thing that leads her to kill her baby girl in an attempt to save her from suffering the same fate. Throughout the course of events, Morrison reflects how Sethe's past presented through the baby's ghost - haunts her present, and how she starts to reconcile with her past trying to figure out a better future. As for Ashour's $\mathrm{Al}$ Tantoureya, it recalls the journey of a Palestinian girl who is forced out of her land by Israeli forces. Rokkaya, the protagonist, starts her story at the age of thirteen and narrates her long and diverse life as an unsettled refugee. That is, she symbolizes and presents a diverse type of Diaspora. Through Rokkaya as the protagonist and narrator - who uses both 1st and 3rd person narration to 
tell her own story- Ashour tries to reestablish the Palestinian history, together with reflecting the pain and resistance involved within this continuing quest for restoring the Palestinian homeland and identity.

As mentioned above, memory is the source of information the reader receives; the trigger of thought, emotions and actions for the main characters. Memory is dealt with as the source of power as well as destruction. In Beloved, Morrison highlights the importance of the past - or rather memory in shaping the present and the future. Memory in the novel is not personal memory, it is rather a cultural one that aims at "keeping the past alive in order to construct a better future" ( Davis, 2). Memory - or the past - is embodied in the character of Beloved that haunts the lives of the characters till she actually appears and leads to their destruction. Her presence is counteracted by that of Denver who represents the future and the importance of transcending this destructive past. In Al-Tantoureya memory is embodied in the past details related by Rokkaya who herself stresses the need to overcome these harsh memories to lead a healthy future. That is, Rokkaya is symbolic of both the past, present and future of the disoriented Palestinians. I will start by discussing the development of both protagonists of the two novels, then venture into the role played by nature and community in reflecting both tackled cultures.

Sethe first appears as a woman in her mid-30s living in an Ohio farmhouse with Denver and Baby Suggs. She lives an isolated life with her memories and the ghost of her slaughtered baby. The mere choice of infanticide as the main theme of the novel, highlights Morrison's dramatization of the effect of slavery and the cruelty of this most bloody anti-family institution. The novel opens by a description of Sethe's house: 
124 was spiteful. Full of a baby's venom. The women in the house knew it and so did the children. For years each put up with the spite in his own way, but by 1873 Sethe and her daughter Denver were its own victims" ( Beloved, 3).

This introduction is followed by Paul D.'s visit and his conversation with Sethe that opens various hidden realms of secrets and memories. The reader gets to know about the disappearance of Halle - Sethe's husband - and also of her sons Howard and Buglar. Moreover, Sethe declares to Paul D. the neighborhood's neglect to her and her daughter: "I can't live here. I don't know where to go or what to do, but I can't live here. Nobody speaks to us. Nobody comes by. Boys don't like me. Girls don't either" (Beloved, 17). However, on Paul D.'s suggestion for Sethe to find herself a different place, she furiously refuses saying:" I got a tree on my back and a haunt in my house and nothing in between but the daughter I am holding in my arms. No more running - from nothing. I will never run from anything on this earth" (Beloved, 18). This short declaration stands for the whole story of the African American Diaspora. Sethe - symbolic of the slave victims - has lost all her ties and family members let alone her daughter throughout her long intricate journey of enslavement and escape. This leads her to seek any kind of settlement even if an isolated one.

Through Sethe's dialogue with Paul D. Morrison relates the cruel conditions of the slaves. One of the worst effects of slavery is that related to the family. Slavery as an institution deprived a whole race with various generations of having a family to belong to; the husbands escape, the kids taken to work in plantations, the mothers deprived of their children, and the siblings themselves not knowing each other: 
In all of Baby's life, as well as Sethe's own, men and women were moved around like checkers. Anybody Baby Suggs knew, let alone loved, who hadn't run off or been hanged, got rented out, loaned out, bought up, brought back, stored up, mortgaged, won, stolen or seized. So Baby's six children had six fathers. What she called the nastiness of life was the shock she received upon learning that nobody stopped playing checkers just because the pieces included her children. Halle was able to keep the longest. Twenty years. A lifetime.... To make up for coupling with a straw boss for four months in exchange for keeping her third child, a boy, with her - only to have him traded for lumber in the spring the next year.... And then [God] gave her Halle who gave her freedom when it didn't mean a thing (Beloved, 28)

The fact of experiencing slavery, this dehumanizing institution that turned its victims into mere objects, has led to an "internalization of this colonizing discourse and subsequently to an inability ... [or] a constant struggle, to develop a self-empowered subjectivity when free from physical slavery" (Eliott, 181). Hence, even after slavery, these freed slaves are unable to pursue a normal healthy life. They always feel chased or rather controlled by their memories that refuse to let them free. This enslaving past is most emblematic in the character of Beloved. Beloved's story is an embodiment of " personal and collective loss: the deprivation of home, abandonment by an enslaved mother, the erasure of a disinherited father" ( Mogler, 23). Furthermore, as previously mentioned, the character of Beloved is Morrison's actualization of memory that passes through several developing phases.

First, these past memories haunt the lives of the members of Sethe's family, and refuse to be discarded. When Paul D. appears as a symbol of those slaves who were able to acquire their freedom, he tries to free Sethe from 
these memories and support her to get involved in her present and community, to find her real buried identity, and to accept herself with her whole experience. Nevertheless, at this moment Beloved reappears but in the form of a real adult, and tries to occupy their lives physically as well as psychologically. Beloved is portrayed skillfully by Morrison. When she first appears as a flesh-and-blood character, her thoughts are distraught and disorganized:

I need to find a place to be the air is heavy I am not dead I am not there in a house there is what she whispered to me I am where she told me... I sit the sun closes my eyes when I open them I see the face I lost Sethe's is the face that left me Sethe sees me see her and I see the smile... she is my face smiling at me (Beloved, 252)

Then gradually, Beloved begins to achieve mental control: "All I want to know is why did she go in the water where we crouched? Why did she do that when she was just about to smile at me? I wanted to join her in the sea but I could not move" (Beloved, 253). Beloved starts to control Sethe, and day after day she drives her to self-destruction, but drives Denver - the symbol of the new generation or rather the future - to start a new life with the surrounding community.

Before analyzing the role of Denver and the community, let's trace the character of Rokkaya In Ashour's Al-Tantoureya. The novel accounts for the history of Palestinian invasion from the perspective of a young Palestinian girl. Although the novel is not written in the period of the Israeli occupation, still it chronicles the whole experience. The novel tackles a different kind of Diaspora than that discussed in Beloved; that of Palestinian refugees. Those refugees are similarly forced to live away from their homeland; but still they leave their land with a hope of return. They are forced out of their land 
because it is needed as part of a plan to pursue western imperial achievements. That is, a refugee always lives with the dream of getting back his stolen country and preserving his Land and memories. Ashour, like Morrison, chooses to tell the story from this perspective to preserve the Palestinian history and "geography that the Zionist enemy strove to eradicate, and to construct instead his own distorted one" (Hafez, 1). Ashour tries to reflect "the struggle for self-determination by Palestinians" who battle for their real identity and image ( Assadi, 2). The novel erases the Zionist established settlements and restores for old Palestine its old beauty; the nostalgic Palestinian image and geography. The novel similarly tackles the problem of the misrepresentation of history, as rendered by Murid Barghuthy:

The cruelest levels of exile is when the person is invisible, when he is not allowed to relate his own story. The story of the Palestinian people is told and defined by their enemy in a way that suits the enemies' presence and the Palestinian absence. They stamp whatever label they wish. The victim is allowed to cry, to scream, and to complain, but he is never allowed to tell his story (qtd. in "Born there, Born here",1).

Like Morrison, Ashour depends in her novel on a female protagonist. Rokkaya is used as a symbol of Palestine and an epic of a people that never loses hope and power of survival. Nevertheless, unlike Sethe, Rokkaya is a strong woman who is totally aware of her dilemma, but who is equally aware of the inevitability of pursuing one's life regardless all sufferings and pain. The story is told by the protagonist herself who gives the reader a full account of her past life in her home town, an also a detailed description of the whole process experienced by the Palestinian refugees in the lands where they migrated. That is, unlike Morrison who concentrates on the post slavery era, 
Ashour relates the story from the very early point of invasion and evacuation to document this controversial period in history.

Al-Tantoureya starts with a flashback description of Tantoura. Tantoura is a Palestinian country on the Palestinian coast around $24 \mathrm{~km}$ away from Hifa. The country falls in the hands of Zionists on the $22^{\text {nd }}$ and $23^{\text {rd }}$ May 1948. This attack is followed by a big massacre the following day on which at least 200 Palestinians are killed. The Israeli soldiers send women and children to a nearby country 'Al Feridis' then 'Al Khalil', then people get scattered among various exiles. Rokkaya is one of those children who are sent with their mothers to the nearby refugee camps, then move from one country to another as is the case with other diasporized Palestinians. The novel opens with the description of the Tantoura of Rokkaya's childhood; the houses, the sea, and the neighborhood: how the children spend their time by the sea, how the townspeople gather daily to discuss various issues, and how family members tightly mingle with each other.

Then Rokkaya takes us suddenly to the present time when all the members of the family are scattered around the world: "The airplane arrival schedule is replaced by one of departure to Abu Dhabi, Toronto,... we go to the airport, then return to go once more.... Crying it became nonsense" ( $\mathrm{Al}$ Tantoureya, 21). As in Beloved, the Palestinian people get used to the sight of dead people and to the daily expectation of receiving the news of the death of close relatives:

I screamed while pointing at a bundle of dead bodies. My Mother looked where I pointed and screamed: Gamil, Gamil my cousin! Then I pulled her arm again...and pointed with my right hand where my father and brothers are. Their dead bodies were next to Gamil's, piling one above the other just few meters away from us" ( Al-Tantoureya, 62) 
Nevertheless, life goes on; Rokkaya gets married to her cousin, she brings up her children, witnesses their growth and development together with their own children, experiences the death or rather the disappearance of her husband courageously, and resumes her life as it leads her. The problem with these refugees is that they have never felt being at home. The countries they migrate to hardly give them the welcoming feeling they might have got in case of being normal immigrants. Although Rokkaya refuses several times to leave her house in Beirut, she finally surrenders saying: " Why don't I take my son and daughter and leave this place which tells us implicitly: leave this place, you are strangers. Have I said implicitly? No, I am wrong. They say it frankly each and every day. I saw it written on walls" ( Al-Tantoureya, 259). Barbara Parmenter claims that the Palestinian refugees suffer the disadvantage of being members of a community. This feeling has been frequently experienced when these Palestinians were expelled or fired from various countries because of political or social reasons (68). This leads to what Edward Ralph calls "Existential outsidedness" (51), which in turn results in "alienation, homelessness, and a sense of the unreality of the world" ( Parmenter, 68). This feeling is only overcome through community whose role will be discussed later in this study.

As in Beloved, the source of the information we get is memory. However, the impact and nature of memory in Ashour's work is different. In both works, memory is a weapon of destruction as well as a source of life and power; however, unlike Sethe, Rokkaya is aware of that. Rokkaya is aware of the importance of interaction with reality and the present to resume her life. While her son Hassan tries to force her to remember all past details and document them as a way of preserving the whole Palestinian experience, she tries to resist his urge saying: 
What is the use of remembering what we love and restoring it through words? When our beloved dies we bury him.... We cry.... We know that we bury him to pursue our life.... What is wise in running after memory when it tries to escape from its own self?... Do I want to kill it in order to live? Or do I need to revive it even if this leads to my own death? ( Al- Tantoureya, 188)

This does not mean that Ashour is against memory; on the contrary, she stresses the need of memory as the main weapon to preserve culture and history, and also as a way of regaining the usurped Palestine. Palestine for the refugees has been portrayed throughout the novel as a preserved, locked image of fertility and freedom, a "nostalgic vision of a past place lost forever to the refugee....[and thus], is an aesthetic creating incorporating memories and ideals that can survive unperturbed in the individual's psyche" ( Parmenter, 70). This very idea is stressed through the use of the metal keys hung around the necks of the female Palestinians. These keys are even considered a heritage which should be passed from one generation to another. This key is a symbol of their lost homes and a reminder of pursuing resistance to regain Palestine. At the beginning of the novel Rokkaya comments on the key she finds under her mother's clothes saying:

Later I will get to know that most women of the camp carry their house keys exactly as my mom did. Some used to show it to me while relating the story of their country; while some other times I could glance the end of the rope surrounding their neck,...and other times I saw neither of them, but was aware of its presence underneath the dress ( $A l$ Tantoureya, 93) 
Near the end of the novel, Rokkaya meets her son and his daughter - Rokkaya Jr. - in Palestine on the other side of the borders and thinks of giving her the key as a present that she must preserve:

I give the baby to the woman standing next to me. I reach my breast. I touch the chain that carries her name.... I touch the key. I take off the rope from my neck. I put it round hers..... This is the key of our home Hassan; my present to young Rokkaya (Al-Tantoureya, 453).

One major constituent of memory is Place. Both concepts are closely related to each other, since memory preserves events, places and people in a way that may be completely opposite to that of their actual appearance. Edward Ralph argues that when place is experienced as home, it "provides a point of departure from which we orient ourselves and take possession of the world" (40). Sethe tells Denver once: "I was talking about time. It's so hard for me to believe in it. Some things go. Pass on. Some things just stay. I used to think it was my rememory.... Places are still there. If a house burns down, it's gone, but the place - the picture of it - stays, and not just in my rememory, but out there, in the world" ( Beloved, 43). In both African American and Palestinian cultures, place is mostly equals to nature. In Beloved as well as $\mathrm{Al}$ Tantoureya, nature is treated as a character in itself; it acts as a resort and solace to any distressed character. It is also used as a silent element of discourse that speaks voicelessly of all sufferings embedded within these hidden stories, and stands for the ever living resisting voice.

Our first encounter with nature in Beloved is with Denver's bower:

Back beyond 124 was a narrow field that stopped itself at a wood.... In these woods ...five boxwood bushes, planted in a ring, had started stretching toward each other four feet off the ground to form a round, empty room seven feet high, its walls fifty inches of murmuring leaves. 
Bent low, Denver could crawl into this room, and once there she could stand all the way up in emerald light. It began as a little girl's house play...then a refuge (Beloved, 34-35)

Not only Denver, but also Sethe finds her solace in the Clearings. When she is all surrounded with miseries and harsh memories, she decides "to go to the Clearing, back where Baby Suggs had danced in sunlight" (Beloved, 101). That is, this place reminds Sethe of Baby Suggs - the representative of the Negro wisdom in the novel - who speaks to the Negro neighborhood what Morrison wants to speak to the whole world:

Here.... In this very place, we flesh that weeps, laughs; flesh that dances on bare feet in grass. Love it. Love it hard. Yonder they do not Love your flesh. They despise it. They don't love your eyes.... And O my people they don't love your hands. Those they only use, tie, bind, chop off and leave empty. Love your hands! Love them. Raise them up and kiss them. Touch others with them.... Love your heart. For this is the prize (Beloved, 103-104)

This same place is that chosen by the neighboring community to exorcise Beloved's spirit. Even when Paul D. Speaks of his past memories on the plantation in Sweet Home, the best memories are related to trees: " Trees were inviting; things you could trust and be near; talk to if you want to" ( Beloved, 21).

A very important reference to nature in the novel is the tree on Sethe's back. Sethe's tree is not a natural one, it refers to the scar on her back as a result of Schoolteacher's whip. Amy - Sethe's white savior - is the one who gives it this description: "A Chokeberry tree. Trunk, branches, and even leaves" (Beloved, 16). In an attempt to restore her self confidence, Paul D. describes this scar to her: 
It's a tree.... A Chokeberry tree. See, here's the trunk - it's red and split wide open, full of sap, and this here is the parting of the branches. You got a mighty lot of branches.... Your back got a whole tree on it. In bloom. What God have in mind, I wonder (Beloved, 93)

In this case, the tree is not associated with greenery and security; it rather stands for extension and continuity. That's why Paul D. - in an attempt to help her regain her sense of lost self - touches the tree on her back: "He held her breasts in the palms of his hands. He rubbed his cheek on her back and learned that way her sorrow, the roots of it; its wide trunk and intricate branches" ( Beloved, 20).

In Al-Tantoureya, the Palestinian refugees are plunked off their homelands and are faced with the challenge of coping and mingling with different ones. After the 1947-1948 war, 750,000 Palestinians turned into refugees. These evicted Palestinians took refuge in the West Bank, or in the Gaza strip, while others fled to Lebanon and Syria. The countries the Palestinians were transferred to "often contrasted markedly with the lands left behind" (Parmenter, 49). The severity of their experiences is hence highlighted through the contrast between these two widely opposed settings. Rokkaya's family used to live in a coastal village, but was forced to inhabit a harsher and a more severe environment. Nature in the novel is presented through two major symbols: the sea and the trees. The novel opens with the sea, as if it is a real character opening up the events and introducing the whole story. The sea is an integral part of the Palestinian community. The first love that Rokkaya experiences is related to the sea:

He came out of the sea...as if part of it and thrown by the waves.... I followed him while he was walking straight towards the beach.... He 
was bare except for a thin white pair of trousers, and water drops were twinkling above his face and shoulders ( Al- Tantoureya, 7)

The sea is further described as the source of the village's life:

The sea borders the village. It lends it its sounds and colors. It veils it with its odor that we smell even in our bread. I can't remember when I have learnt to swim exactly as I can't gather when I have learnt walking or talking. Even after years, I tried to settle in one of those coastal cities as Alexandria or Beirut thinking that the sea is the same. But it was not the case; the city's sea is different, you look at it from a high window, or you walk near it separated by a fence or a wide space. And if you decide to go to it, you go as a stranger... For a temporary visit after which you leave (Al-Tantoureya, 9)

Whereas in the village, the houses are integral with the sea, people go at any time, play in the sand and simply be covered with it. The children spend all their time freely at its shore. Even weddings are held near the sea that is described by the author as one of the guests who enjoys the wedding and feels tired after it. When compared to the train, the sea is portrayed as a symbol of stability and serenity, while the train is a temporal vehicle that comes daily with its harsh disrupting noise that shakes the stable land.

Besides the sea, the almond tree is equally important. This specific type of trees is typical to Palestinian culture and has widely been presented in the literature of Palestinians to represent their lost paradise. In "In the Deserts of Exile" Jabra conjures up his lost paradise:

O land of ours where our childhood passed

Like dreams in the shade of the orange grove,

Among the almond trees in the valleys (in Algar, 226) 
This recurrent image is apparent in Rokkaya's description of the almond tree in her lost village:

The almond tree is the queen of the village. No tree dares to compete with it. Even the sea and its waves envy the tree in Spring.... We don't wait till the almond ripens; we quickly pinch it from the near branches, and climb the far ones till we reach it (Al-Tantoureya, 23)

Furthermore, trees are related to women; to life and fertility. Through one of Rokkaya's moments of meditation, Ashour highlights this issue: "Each woman is a tree. I mean each woman has a tree. There is Om Samir's Lemon tree. Om Ilas' Orange tree "(Beloved, 149). Even at the end, when she goes to live in Alexandria with Mariam, Rokkaya tries to overcome her nostalgic feelings by planting small gardens in her house. She starts with one in her balcony:

I sometimes wonder and say that I try to overcome my nostalgia and long wait. Other times I get deeply involved in my small garden.... [this small garden] became my sole interest and solace.... This is the first garden.... The second garden is a small one in the kitchen on the table under the big window.... The third one is outside the house (AlTantoureya, 399-400)

These natural phenomena represent for the Palestinians their lost paradise that they seek to regain. Clinging to any traces of these past memories endows Rokkaya and her likes with the power of surviving the harsh twists of fate they encounter throughout their quest for survival.

After discussing the importance of nature, the role the community plays in both novels is not less important. Community is related to the concept of home, and both terms "are invoked as the cure to no end of social ills" (Jesser, 1). In both novels, community substitutes the lost homes and act as the only provider of strength and relief. It gives the characters the power to 
stand against all miseries and oppression. Morrison underlines Sethe's isolation from community as the main reason for her dilemma, and presents interacting with the community as the only cure for all her troubles. Whereas in $\mathrm{Al}$ Tantourya, Ashour portrays the lives of Palestinians as one depending on the community from the very beginning. We are not given another alternative for life. Characters are able to pursue their life only through each other.

Morrison's Beloved represents the author's "preoccupation with the effect of the community on the individual's achievement and retention of an integrated, acceptable self' ( Lee, 346). The obstacles that these slaves encounter lead to "fragmentation of both body and mind"; fragmentation which can only be overcome through unity with the surrounding community ( Powell, 143). Through the community, characters in Beloved "free themselves to yoke together stories and bodies, spirit and flesh, and to begin forging a sense of self that holds the promise of the future" (Powell, 144). The slaves' stories and histories are nearly the same; they share various experiences and sufferings. That's why their presence is crucial for each other, and their absence is equally destructive. Community here plays a double role: at the beginning, it symbolizes the soothing power that heals the wounds caused by the slaves' long born sufferings. While in some other instances, it is the cause of Sethe's isolation and destruction. When Sethe escapes from the plantation at the beginning, she heads to Baby Suggs' where she meets with the slave community. Sethe's twenty-eight days of freedom give her the chance to mingle with a common community:

Sethe had had twenty-eight days...of unslaved life.... Days of healing, ease and real talk. Days of company: knowing the names of forty, fifty other negroes, their views, habits; where they had been and what done, 
of feeling their fun and sorrow along with her own, which made it better (Beloved, 111)

Then after Sethe's act of infanticide, all the neighborhood decides to ostracize her, an act that leads to her isolation together with her daughter Denver. That is, Sethe becomes the community's outcast and adapts herself to such a life. This remains until the appearance of Paul D. Who restores Sethe's link with the outer world. His presence gradually replaces that of the ghost and signals a new life. When he walks with Sethe and Denver, "all the time the three shadows that shot out of their feet...held hands...it was a good sign. A life. Could be" (Beloved, 57).

After Denver's attempts to save her mother and her own self by seeking help from the neighborhood community, they start to approach 124 once more to leave some food for this starving family. Gradually, the story of the reappearance of Beloved and of Sethe's torture by the returning daughter spreads throughout the neighborhood, leading a group of thirty women to go to 124 to free Sethe from this humanized ghost:

They grouped murmuring and whispering.... Denver waved. A few waved but came no closer.... A woman dropped to her knees. Half of the others did likewise. Denver saw lowered heads, but could not hear the head prayer (Beloved, 304)

This approach on behalf of the community encourages Sethe to resort to its healing power once more:

Now [Sethe] is running into the faces of the people out there, joining and leaving Beloved behind. Alone. Again. Then Denver, running too, away from her to the pile of people out there. They make a hill. A hill of black people, falling. And above them all, rising from his place with a whip in his hand, the man without skin, looking (Beloved, 309) 
That is, throug community, Sethe succeeds to overcome her past and destructive memories, and finds a way out into the present and future.

In Al-Tantoureya, the characters undergo a shift in the nature of community after the Israeli occupation; these refugees have to either live in refugee camps or with relatives, or rather flee to other Arab countries. In the early part of the novel, Ashour draws the Palestinian community as a cohesive, loving one where all people mingle together and are part of each other. Even when the people of Tantoura get the news of the Jewish occupation of their village, they receive the news together and react to it as one entity. All the men of the village gather around the radio daily in the hall of the chief's house to hear the coming news and hold discussions, while women are not allowed to enter but just receive these news and exchange them. When the Israeli forces start to destroy and occupy Palestinian villages, the whole community acts as one entity and they all share their parts. Rokkaya, our witness of this historical trauma, recounts the early memories of the coming of refugees from neighboring villages: "our village hosted some families, and our share was a widow with two children" Tantoureya, 28). Even when Ashour presents the cruel image of the killed men, they are even piled one above the other as emblems of suffering the same dilemma. This scenario has been repeated all through the Palestinian experience.

However, after the Israeli attacks that turn these innocent natives into refugees, their lives change. They now become guests on relative families in foreign countries that most often unwelcome them. The hosting communities to which they migrate start to become threatened and attacked by Israel as a reaction for aiding the Palestinians, the thing that leads the refugees to keep shifting from one country to another. Rokkaya has to accept the dispersion of 
her children al through the world. She herself gives in and leaves her house and travels with Mariam to complete her studies. This is not the case with Rokaya alone; it is rather the norm of the lives of all refugees. That is, the Palestinians hardly settle into one place that might substitute their homeland. Nevertheless, even in these hard conditions, these people try to find security through one another to replace this nostalgic feeling accompanying this experience of Diaspora.

From the above analysis of Toni Morrison's Beloved and Radwa Ashour's Al-Tantoureya, it has been shown how these two female authors uncover the hidden details of two marginalized races: the Afro Americans and the Palestinians. Their presentations reflect Foucault's theory of power. Power is not only related to that of tyranny and violence; on the contrary, it is rather " the way in which knowledge circulates in a culture... the way in which what we think, what we think that it is appropriate to think...is distributed by largely unseen forces in a social network or a social system" Fry, 2). That is, the real power is the power to control and spread knowledge; knowledge which the dominant power produces. The foregoing argument accentuates new-historicism that confirms the power of language and discourse in shaping history and the world itself. As far as this study is concerned, the histories of these two significant experiences have long been presented by the dominant power - the White Americans and the Jews - in a way that has hardly reflected any truth. Therefore, African American authors as well as Palestinian ones try to fight back using the same weapon: discourse. Toni Morrison and Radwa Ashour present in the novels under study the other aspect of history; that which is experienced by the weak dominated races who have been deprived of speaking out, and if allowed to, are rarely believed. 
The two authors use the same method which is telling the story of the private life of their female protagonists despite talking of two completely different eras and histories. Sethe's destroyed and miserable life underlines the severe cruelty accompanying the institution of slavery. The act of infanticide stresses the dehumanization of the lives of the Afro Americans, who are deprived of their identity and individuality. Sethe's process to regain this stolen sense of self is the main core of Morrison's work. Whereas in $\mathrm{Al}$ Tantoureya, relating Rokkaya's displacement together with her family, is meant to draw the world's attention to this diasporized race of people who have found themselves overnight refugees scattered all through the world. Their attempt to adapt to the various communities to which they resort, and their cherished hope of returning to their homeland is the focus of the novel. Hence, despite the difference in tackling the issue, still both authors succeed in reminding the readers and the whole global community of some forgotten people who are misrepresented and whose voice has been silenced through the discourse of the dominant power. 


\section{Works Cited}

Al Barghouthy, Murid. “ Tantoureya and the Hope of Return.” Radio and Television Magazine. June 2011.

Al-Assadi, Wesam. “Palestinian Diaspora Goes Global Through American - Palestinian Prose". http://www.walasadi@,aus.edu.

Algar, Hamid and Mounah Khouri (eds.). An Anthology of Modern Arabic Poetry. Berkerly: University of California Press, 1974.

Ashour, Radwa. Al Tantoureya .Cairo: Dar El Shorouk, 2011.

Awilentz ,Gay. “ Toward a Diaspora literature: Black Women Writers from Africa, the Caribbean, and the United States”. JSTOR College English, vol. 54, Number 4, April 1992.

Bressler, C E. Literary Criticism: An Introduction to Theory and Practice. New Jersey: Pearson Education, 2007.

Cawn, Brad. Teaching Toni Morrison's Beloved from Multiple Cultural Perspectives. http://www.prestquickhousecom/PDF/SAMPLE/305397.pdf

Changizi, Parisa and Parvin Chasemi. A Foucauldian Reading of Toni Morrison's Beloved. Shiraz: Shiraz University, 2012.

Darwish, Mahmoud. Yawmiyat Al-Huzn Al-Adi. Beirut: Dar al-Awdah, 1978.

Davis, Kimberly Chabot. “Postmodern Blackness: Toni Morrison's Beloved and the End of History- Novel by Black Female Author". Twentieth Century Literature. Jul.2011. http://findarticles.com. 
Eliott, Mary Jane Suero. "Postcolonial Experience in a domestic Context: Commodified subjectivity in Toni Morisson's Beloved". MELUS. Vol 25, Winter 2000.

Felluga, Dino. “General Introduction to New Historicism.” Introduction Guide to Critical

Theory. http://www.purdue.edu/guidetotheory/newhistoricism/modules/introduction.html

Fry, Paul. "Intoduction to Theory of Literature."

http://www.core.org.cn/mirrors/Yale/yale/oyc.yale.edu/english/introduction-to-theory-of-

literature/content/transcripts/transcript-19-the-new-historicism.htm

Gates, David. “Keep Your Eyes on the Prize”. Newsweek. 18 October 1993.

Hafez, Sabry. “Al Tantoureya: Writing the Palestinian Pain/Hope”. Al Shorouk. June 2011. http://wwwshorouknews.com/columns.

Lee, Doothy H. “ The Quest for Self: Triumph and Failure in the Works of Toni Morrison”. Perspectives On Black Women Writers. Ed. Barbara Christian. New York: Pergamon Press, 1985.

Hamilton, Paul. Historicism. London: Routledge, 2003.

Jenkins, Keith. Refiguring History. New York: Routledge, 2003.

Jesser, Nancy. “ Violence, Home, and Community in Toni Morrison's Beloved". http://www.findarticles.com/p/articles.

Mogler, Helene. “Redeeming History: Toni Morrison's Beloved”. Cultural Critique, Spring 1993.

Morrison, Toni. Beloved. London: Vintage Books, 2005.

. "Scars and Self-Definition in Beloved". http://web.archive.org/web 
Parmenter, Barbara McKean. Giving Voice to Stones. Austin: University of Texas Press, 1994.

Powell, Jane. "Will the Parts Hold?: The Journey Toward a Coherent Self in Beloved". Understanding Toni Morrison's Beloved and Sula: Selected Essays and Criticisms of the Works by the Nobel Prize-Winning Author.Eds. Solomon O. Iasere and Maria W. Iasere. Troy: Whitson, 2000.

Relph, Edward. Place and Placelessness. London: Pion Press, 1976.

Rigney, Ann. Imperfect Histories: The Elusive Past and the Legacy of Romantic Historicism. Ithaca and London: Cornell University Press, 2001.

Rody, Caroline. "Toni Morrison's Beloved: History, Rememory, and a Clamour for a Kiss." Understanding Toni Morrison's Beloved and Sula: Selected Essays and Criticisms of the Works by the Nobel Prize-Winning Author.Eds. Solomon O. Iasere and Maria W. Iasere. Troy: Whitson, 2000.

Ruman, Abdul Karim. " Construction of the Racial Identity by Gaze and Blindness in The Bluest Eye and Native Son". http://www.articlebase.com. 